
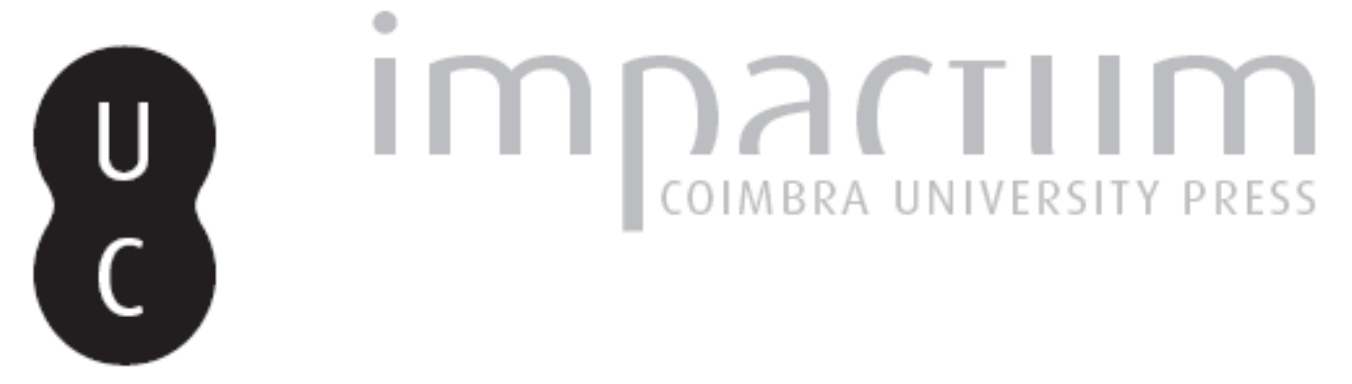

\title{
Sobre a dispersão dos Tapori: algumas notas de reflexão
}

\section{Autor(es): $\quad$ Ferreira, Ana Paula}

Publicado por: Imprensa da Universidade de Coimbra

URL persistente:

URI:http://hdl.handle.net/10316.2/45375

DOI:

DOI:https://dx.doi.org/10.14195/1647-8657_39_5

Accessed : $\quad$ 26-Apr-2023 14:56:37

A navegação consulta e descarregamento dos títulos inseridos nas Bibliotecas Digitais UC Digitalis, UC Pombalina e UC Impactum, pressupõem a aceitação plena e sem reservas dos Termos e Condições de Uso destas Bibliotecas Digitais, disponíveis em https://digitalis.uc.pt/pt-pt/termos.

Conforme exposto nos referidos Termos e Condições de Uso, o descarregamento de títulos de acesso restrito requer uma licença válida de autorização devendo o utilizador aceder ao(s) documento(s) a partir de um endereço de IP da instituição detentora da supramencionada licença.

Ao utilizador é apenas permitido o descarregamento para uso pessoal, pelo que o emprego do(s) título(s) descarregado(s) para outro fim, designadamente comercial, carece de autorização do respetivo autor ou editor da obra.

Na medida em que todas as obras da UC Digitalis se encontram protegidas pelo Código do Direito de Autor e Direitos Conexos e demais legislação aplicável, toda a cópia, parcial ou total, deste documento, nos casos em que é legalmente admitida, deverá conter ou fazer-se acompanhar por este aviso.

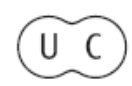


UNIVERSIDADE DE COIMBRA

FACULDADE DE LETRAS

\section{CONIMBRIGA}

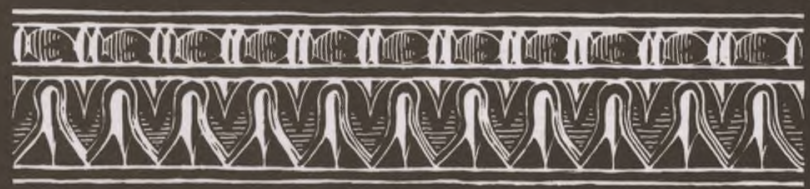

VOLUME XXXIX - 2000 
ANA PAula FERreira

Licenciada em Arqueologia

SOBRE A DISPERSÃO DOS TAPORI: ALGUMAS NOTAS DE REFLEXÃO "Conimbriga" XXXIX (2000) p. 153-189

RESUMO: A autora, restringindo-se geograficamente à Península Ibérica, procurou abordar a problemática dos limites geográficos da civitas dos Tapori, recorrendo para tal à análise da dispersão de monumentos epigráficos alusivos a essa etnia através da presença de um etnónimo ou de um antropónimo de origem étnica.

RÉSUMÉ: L'auteur, en se limitant á la Péninsule Ibérique, a étudié la problématique des limites géographiques de la civitas des Tapori, en utilisant pour cela 1' analyse de la dispersion de monuments épigraphiques concernant cette éthnie par la présence d'un ethnonyme ou d'un anthroponyme d'origine ethnique. 
(Página deixada propositadamente em branco) 


\section{SOBRE A DISPERSÃO DOS TAPORI ALGUMAS NOTAS DE REFLEXÃO}

\section{Introdução}

O tema da geografia política constitui um dos assuntos que mais tem apaixonado os historiadores e arqueólogos contemporâneos. E é esse também o foco da nossa atenção neste trabalho.

Não existia, à chegada dos Romanos ao nosso território, uma unidade étnica, linguística ou cultural. Por exemplo, entre o Douro e o Tejo estavam instalados diversos povos. Nomeadamente, um conjunto de populi da Beira Interior a quem foi aplicado o colectivo Lusitani (ALARCÃo 1988' pp. 15-16), entre os quais se encontra aquele que ora nos ocupa.

O reordenamento territorial efectuado pelos Romanos passou pela definição de civitates (vasto território que abarcava uma capital, outros aglomerados urbanos secundários e ainda o povoamento rural) e de uma rede viária que facilitava as comunicações, contribuindo assim para a integração das populações na respectiva civitas (ALARCão 1988' p. 10). Na definição territorial destas civitates, os Romanos atenderam não apenas aos limites geográficos naturais, mas também às divisões etnicoculturais pré-existentes e, muitas vezes, fizeram coincidir os limites de uma civitas com os de uma anterior unidade étnica ou política (Alarcão 1990 p. 360).

É precisamente o tema desta abordagem o problema da civitas dos Tapori, que Plínio ( NHIV 118) cita ao enumerar as civitates stipendiariae da Península. Tapori que correspondem, muito provavelmente, aos Talori citados na conhecida inscrição da ponte de Alcântara (CILII760).

A origem deste populus é desconhecida e a sua localização permanece envolta em dúvidas. Na verdade, os limites geográficos deste populus foram traçados, pela primeira vez, por Russell Cortez (1952); 
Jorge Alarcão e Flávio Imperial (1996) voltaram recentemente a discuti-los. Tal discussão pode assentar, por exemplo, na análise da dispersão geográfica de elementos pertencentes a essa etnia, tendo por base os monumentos epigráficos.

$\mathrm{Na}$ realidade, não é frequente a menção da origo nas inscrições, nomeadamente nas funerárias, pois o defunto era habitualmente natural do local onde era enterrado e, neste caso, a naturalidade não seria elemento identificador. Desta sorte, a menção da origo numa epígrafe indica a procedência do indivíduo que é alheio à população local (ENCARNAÇ̃̃o 1994 p. 650).

Muitas vezes, porém, a origem dos indivíduos surge na identificação onomástica, isto é, o cognomen e o nome único adquirem particular interesse quando eles próprios correspondem à adopção de um etnónimo, como lembrou Jürgen Untermann (1965 p. 99) em relação a Celtiber, que falta na própria Celtibéria, ocorrendo somente em zonas marginais a esta região e em outras partes da Península: o antropónimo é o étnico que podia atribuir-se a celtiberos imigrantes em países não celtiberos. Situação semelhante à que ainda hoje acontece quando nós, na região centro, e porque não estamos no Alentejo, identificamos alguém como o "João Alentejano".

Foi esta pista que procurámos seguir em relação aos Tapori: detectar nas inscrições indivíduos que, porque tiveram necessidade de emigrar, acabam por referir a sua procedência, quer através de um etnónimo quer de um antropónimo de origem étnica.

Restringindo-nos geograficamente à Península Ibérica, fizemos a pesquisa e recolha de todas as epígrafes alusivas a Tapori. Acontece, porém, que até a obra recente de Abascal Palazón, Los Nombres Personales en las Inscripciones Latinas de Hispania (1994), regista apenas oito referências a Tapori. Desta resultou a elaboração de um catálogo, organizado de Oeste para Este (colocando em último lugar uma inscrição de origem incerta). O reportório que este catálogo contém abrange informações diversificadas de cerca de 62 individuos, que figuram em 24 inscrições.

Surgiram, entretanto, alguns problemas metodológicos, nomeadamente pelo facto de muitas das inscrições carecerem de rectificações de leitura. No entanto, não foi nossa preocupação nem objectivo deste trabalho fazer a inspecção directa dos monumentos a fim de corrigir possíveis erros de leitura, pelo que a investigação se fez recorrendo apenas às publicações. São portanto essas publicações que se seguem, 


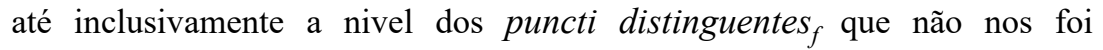
possível verificar se o eram realmente ou se se tratava de meros sinais gráficos usados pelos diferentes autores.

Pretendemos, tão somente, escalpelizar as epígrafes, fazendo delas uma análise minuciosa, prudente e não conclusiva das informações aí inseridas.

Muito haverá ainda a caminhar para se chegar a um consenso. No entanto, esperamos de alguma forma ter contribuído para aclarar esta página da nossa História.

\section{Dispersão geográfica dos Tapori}

\section{A localização dos Tapori}

A conquista romana da Península Ibérica iniciou-se em 218 a. C., com o desembarque das tropas de Cneu Cipião em Ampúrias (Alarcão $1988^{1}$ p. 13), tendo sido concluída por Augusto (ALARCÃo $1988^{1}$ p. 28).

Nos primeiros tempos do principado de Augusto, a parte montanhosa da Lusitânia, ao norte do Tejo, havia pouco que tinha acabado de ser pacificada. E a pacificação definitiva do território entre Tejo e Douro não teve lugar antes de 44 a.C. Neste território, desde 194 ou 193 a.C. que os Romanos defrontavam os Lusitanos (AlARCÃo 1990 pp. 347-349). Estes corresponderiam não a um populus, mas a um conjunto de populi da Beira Interior ${ }^{1} .{ }^{1}$

1 Provavelmente, segundo Jorge de Alarcão (19881 pp. 15-16; 1990 p. 354; 1992 p. 345), os Lusitanos não eram um populus, mas o nome terá sido aplicado pelos Romanos a um conjunto de populi da Beira Interior, posteriormente convertidos em civitates pelos Romanos. Se também estes fossem um populus teriam sido convertidos em civitas, como os restantes. O conjunto de populi que formavam os Lusitanos seriam os que estão mencionados na inscrição da ponte de Alcântara (CIL II 760) ou, se não todos, pelo menos alguns deles. Ptolomeu regista os Lancienses Oppidani entre os Vettones e os Transcudani pertenciam também possivelmente ao mesmo grupo étnico, por isso devem ser excluídos do grupo dos Lusitanos, assim como também talvez se devam excluir os que ficavam a ocidente da Serra da Estrela, isto é, os Interannienses, os Coilarni e os Paesures.

Assim, quando os Lusitanos chegaram às Beiras, seriam já um grupo de populi agregados por esse etnónimo comum. Ou, em alternativa, podemos considerar um povo 
Concluídas as operações militares do NO, era necessário operarle o enquadramento da população civil na ética romana, subordinando-a a novas formas jurídico-administrativas. Iniciou-se assim, com Augusto, uma reforma político-administrativa da região mais ocidental da Península, nomeadamente da parte portuguesa da Hispánia romana, de forma a fixar ao solo entre o Tejo e o Douro os povos que desde há muito praticavam a transumância. Esta reforma incluiu a criação da província da Lusitânia, a institucionalização e delimitação de civitates ${ }^{*} 2$ e a urbanização das cidades capitais. Simultaneamente foi traçado um programa de rede viária e promovido o fomento da agricultura e da mineração, ou seja, da economia das terras da Lusitânia (ALARCÃo $1988^{1}$ p. 28; MANTAS 1988 p. 417). Neste contexto verificou-se o desenvolvimento de centros urbanos como uma necessidade decorrente da organização geral do território, quer se trate de cidades novas, como Idanha-a-Velha, quer se trate da promoção, através de trabalhos urbanísticos, de núcleos populacionais indígenas, como aconteceu em Conimbriga (MANTAs 1988 p. 417).

Este programa de reordenamento territorial iniciado por Augusto adoptou ideias de Júlio César e a sua aplicação ter-se-á prolongado até à época de Nerva (Alarcão 1990 p. 352). Um dos parâmetros desta política de ordenamento territorial foi a definição de civitates: unidade político-administrativa que ocupava um vasto território, onde se incluía uma cidade capital, aglomerados urbanos secundários e ainda $\mathrm{o}$ povoamento rural. $\mathrm{Na}$ definição destas civitates, os Romanos tiveram muitas vezes em conta as unidades étnico-culturais pré-existentes (ALARCÃo 1990 p. 360).

Não existem provas de que todas estas civitates tenham sido constituídas e demarcadas por Augusto; algumas delas podem ter sido definidas por outros imperadores ao longo do séc. I d. C. (AlARCão $1988^{1}$ p. 35). E se é possível determinar a situação aproximada de

que estabelecido na Beira, em diferentes territórios, se teria dividido em diferentes populi que acabariam por adquirir designação própria (ALARCÃo $1988^{2}$ p. 47).

Recentemente Jorge Alarcão e Flávio Imperial (p. 43), tendo em conta um passo de Valério Máximo que se pode traduzir por "das três cidades da Lusitânia", concluíram que os Lusitanos se limitavam a três civitates, isto é, a três populi. Colocam ainda a hipótese de serem estes os Igaeditani, os Tapori e os Lancienses Ocelenses.

$2 \quad$ Esta fez-se através dos termini Augustales, que nos permitem conhecer os povos visados por esta operação (ALARCÃo e ETIENNE 1976 p. 175). 
algumas delas, como a dos Igaeditani, a de outras é ainda problemática, como é o caso da dos Tapori.

Esta unidade administrativa era dotada de um governo próprio que tinha, relativamente ao governador da província e aos seus agentes, uma autonomia que variava de acordo com o estatuto que pela administração romana lhe havia sido atribuído. Uma dessas categorias é a de oppidum stipendiarium: estes não tinham ius Latii e estavam sujeitos a uma tributação, na maior parte dos casos sob a forma de tributum ou stipendium (ALARCÃo 1990 p. 389). Foi esta categoria que foi atribuída à capital dos Tapori, de acordo com a informação de Plínio ${ }^{3}$ \{Naturalis Historia IV 118).

A inscrição da ponte de Alcântara (CIL II 760) menciona 11 dessas civitates. São elas: a dos Igaeditani, Lancienses Oppidani, Talori, Interannienses, Colarni, Lancienses Transcudani, Aravi, Meidubrigenses, Arabrigenses, Banienses e Paesures. Corresponde esta vasta lista, certamente, às comunidades que participaram na construção da ponte porque lhes interessava aquela via de comunicação (BLANCO FrEIJEIRO 1977 p. 27) que atravessava o Tejo naquele local e entrava em território actualmente português por Segura, passando depois a via pelo território destes povos (AlARCÃo $1988^{2}$ p. 45).

A seguir aos Lancienses Oppidani, a inscrição da ponte de Alcântara cita os Talori, nome que possivelmente se deve corrigir para Tapori $3^{3}{ }^{4}$, pois é sob esta forma que Plínio os menciona e é esta forma que é confirmada por numerosas inscrições (ALARCÃo $1988^{1}$ p. 37).

F. Russell Cortez (1952 p. 178) situa os Tapori na vertente leste da serra da Gardunha, como populações vizinhas dos Igaeditani e dos Lancienses Oppidani. Localização corroborada por D. Antonio Blanco Freijeiro (1977 p. 35 e fig. 7) que afirma que o território dos Tapori se estendia a oeste dos Igaeditani, pela zona da serra da Gardunha.

3 De entre os ópidos estipendiarios, com facilidade se podem citar, para além dos que já referimos quando tratámos dos cognomes das cidades da Bética, os seguintes: Augustobricenses, Aeminienses, Aranditani, Arabrigenses, Balsenses, Caesarobricenses, Caperenses, Caurienses, Colarni, Cibilitani, Concordienses, Elbocori, Interamnienses, Lancienses, Mirobricenses cognominados celtici, Medubricenses que são chamados Plumbari, Ocelenses, Turduli chamados Bardili e Tapori \{Naturalis Historia IV 118).

4 Significa isto que houve, muito provavelmente, um erro na transcrição do texto da inscrição, aquando da feitura da cópia. 
Em 19881, Jorge Alarcão (pp. 37-38) revé esta localização e considera que os Tapori se situariam na vertente oriental da Serra da Estrela, onde os vestígios de povoamento são densos, sobretudo entre os paralelos de Valhelhas e Fundão. Desta sorte, coloca a hipótese de se atribuírem aos Tapori estas estações romanas, não excluindo a integração no mesmo território das poucas localidades romanas da Gardunha. Partindo desta hipótese, aponta como localização da capital dos Tapori o Teixoso, onde se encontrou uma inscrição que menciona um duumvir primus, provando a existência de um município na região. Já Armín U. Stylow (1986 p. 244) considera que o centro da tribo dos Tapori estaria localizado perto da Capinha. As inscrições n. ${ }^{\text {ss }} 3$ e 4, provenientes da região do Fundão, põem em causa estas considerações. Tendo sempre presente que a indicação da origo indica afastamento desse local, a existência de dois epitáfios, de dois indivíduos que, tendo morrido na região do Fundão, referem a sua origem étnica dos Tapori, significa que esta área não pertencia ao territorium deste populus. A inscrição n. ${ }^{\circ}$, proveniente da Capinha, afasta a hipótese de Armín U. Stylow. E se esta epígrafe nos permite inferir que o vicus Talabara pertencia aos Tapori, significa também que este vicus não se situaria, como refere F. Russell Cortez (1952 p. 178), nas imediações da Capinha, mas pelo contrário em local afastado.

Daí que a proposta apresentada, mais recentemente, por Jorge de Alarcão e Flávio Imperial (1996) pareça estar mais próxima da realidade. As alterações em relação aos limites propostos em 1988, passam essencialmente pela revisão da localização dos Lancienses Oppidani. Partindo da conjugação do marco do Salvador (CIF II 460), do terminus de Peroviseu ${ }^{5}$, do texto pliniano e da inscrição da ponte de Alcântara, os autores propõem a existência de três Lancienses à época de Augusto, o que exige a redefinição dos territórios destes populi (p. 39). Assim, acabam por propor a existência nesta região da Beira de cinco civitates: Igaeditani, Tapori, Lancienses Oppidani, Lancienses Transcudani e Lancienses Ocelenses. Tendo os Igaeditani (cujos limites orientais ultrapassavam, talvez, a fronteira luso-espanhola) como referência, situam os Lancienses Oppidani a norte destes, separados pela serra de Penha Garcia e por uma linha artificial que iria do Salvador a Torre dos Namorados e a Capinha, colocando ainda a hipótese

${ }^{5}$ Este terminus encontra-se na estrutura de uma das fachadas do presbitério de pertença do Prior de Peroviseu (cf. Monteiro 1974). 
de Penamacor ser a sua capital; a ocidente destes e ainda a norte dos Igaeditani, ficariam os Lancienses sem outro apelido, citados no marco de Peroviseu, sendo este o limite entre Igaeditani e Lancienses. E sendo assim, o Teixoso, antes apontado para capital dos Tapori, parece corresponder à capital dos Lancienses. Os Lancienses Transcudani ficariam situados no planalto da Guarda/Sabugal. Desta forma, os teriam como limites, a ocidente, a serra do Muradal, a ribeira do Alvito e o rio Ocreza (ou aquela linha montanhosa onde se situam os marcos geodésicos de Almeirão e Pinheiro Gordo); a norte, a serra da Gardunha; a oriente, a ribeira de Alpreade e o rio Pônsul (ou uma linha artificial que desceria, desde a confluência da ribeira de Alpreade com o Ponsul, sobre Malpica do Tejo) e, a sul, o Tejo (pp. 40-42).

De qualquer forma, os limites do territorium dos Tapori parece coincidir, pelo menos em parte, com a herdade da Cardosa que D. Afonso II doou, em 1214, aos Templários (CARDoso 1944 pp. 16-18). Apenas a ocidente os limites parecem divergir, abrangendo a herdade menos território. Nesta vasta herdade, J. Ribeiro Cardoso (1944 p. 18) dá a notícia da existência de sinais evidentes da presença romana, que se iam conhecendo através dos trabalhos agrícolas.

Quanto à capital dos Tapori, cujo nome permanece uma incógnita, poderia ter sido Castelo Branco ou algum povoado entre as ermidas da Senhora de Mércoles, Santa Ana e São Martinho.

José Manuel Garcia (1979 p. 153; 1984 p. 95) sugeriu, embora com reservas, que na região de Castelo Branco se poderia situar a cidade de Concordia, referenciada por Ptolomeu ( V 6) na região a norte do Tejo, sendo o étnico dela derivado também mencionado por Plínio entre os oppida estipendiários. Esta hipótese teve origem na lápide funerária de um indivíduo que parece identificar-se como concordiense, que apareceu na Cadaveira, local próximo de Vila Velha de Ródão, região que, segundo este autor, poderia ser habitada pela população com aquele nome. Já Vasco Gil Mantas (1985 p. 228) considera que não há, na argumentação apresentada, nada que autorize tal localização, tendo sempre presente que a referência à origem normalmente indica afastamento do local do achado.

Afastada, portanto, a hipótese de Castelo Branco corresponder a esta cidade, nada impede, no entanto, que aqui exista um vicus ou até mesmo a capital dos Tapori. Se não no perímetro da actual cidade, algures nos seus arredores. A cerca de $3 \mathrm{Km}$ a sueste de Castelo Branco, no triângulo formado pelas ermidas da Senhora de Mércoles, 
Santa Ana e São Martinho, existe uma baixa onde são conhecidos vestígios romanos abundantes e dispersos (ALARCÃo 19883p. 76; ALARCÃO 1990 p. 371; Alarcão e ImPerial 1996 p. 42). Partindo desta notícia, realizámos uma pesquisa no terreno, na tentativa de esclarecer a questão, delimitando esses mesmos vestígios.

Percorrendo toda essa superfície, pudemos verificar que, na realidade, os vestígios existem, concentrando-se na baixa entre a Senhora de Mercóles e Santa Ana, em três núcleos, ocupando uma extensão bastante vasta. Porém, é preciso ter em atenção que esta é uma região bastante agricultada, por um lado, e já sujeita a construções, por outro, e portanto é natural que os vestígios se tenham dispersado por uma área maior.

$\mathrm{O}$ primeiro núcleo de vestígios encontra-se em redor da capela de Santa Ana, nomeadamente nos terrenos que pertencem actualmente à Escola Superior Agrária de Castelo Branco. Aqui encontrámos quase continuamente cerâmica de construção, inclusivamente na própria estrada de acesso, nos canteiros que rodeiam a referida capela.

Alguns metros adiante, junto da capela da Senhora de Mércoles, nos terrenos que a circundam, é grande a densidade de vestígios, mas infelizmente de uma forma muitíssimo fragmentada, dadas as diversas construções no local. Além da cerâmica de construção, aqui se encontraram vários fragmentos de cerâmica comum e, inclusivamente, terra sigillata. Ainda nesta área, nos muros que circundam os terrenos se encontram quer fragmentos de cerâmica de construção, quer pedras aparelhadas, que poderão ascender ao período romano.

Outro núcleo com grande densidade de vestígios situa-se numa propriedade agrícola, com cerca de $7850 \mathrm{~m}^{2}$, que fica sensivelmente a meio das duas ermidas referidas. Esta propriedade, actualmente um olival, foi dividida ao meio pelo caminho de acesso que, por ser em terra batida, ainda conserva, embora de forma muito fragmentada, vestígios da presença romana. O olival apresenta um número verdadeiramente surpreendente de vestígios, abarcando desde tegulae e imbrices, tijolos de coluna, até fragmentos de dolia.

Estes três núcleos, dada a sua proximidade e o facto de entre eles existirem vestígios pontuais de cerâmica de construção, devem fazer parte de um mesmo aglomerado populacional, cujos vestígios se dispersaram por uma área que ultrapassa os $650000 \mathrm{~m}^{2}$. Actualmente, provavelmente, formaram-se diferentes núcleos devido à abertura da estrada municipal que liga Castelo Branco à Senhora de Mércoles, bem como pela construção de habitações. 
Depois, temos um outro núcleo de vestígios, afastado dos anteriores, no Monte de São. Aqui, além da notícia da existência de fragmentos de cerâmica de construção, há ainda a notícia do achado de três fragmentos de aras e quatro inscrições (GARCIA 1979 p. 151 nota 3). No local, verificámos apenas a existência, muito escassa, de fragmentos de construção, mesmo em redor da ermida, que se situa em cota elevada junto a um marco geodésico. Dada a escassez de vestigios e as características topográficas do local, é nossa opinião que este seria, de longe, mais propício a um santuário que a qualquer outro tipo de ocupação: o isolamento e a altitude do local, dominando visualmente urna vasta área, convida à meditação. Neste sentido está a existência actual de uma ermida no local, cuja presença pode indiciar a continuação de um culto que vem de longe.

Devemos admitir, tendo em conta a acumulação de vestigios e o achado das inscrições em São Martinho, a hipótese de se situar na superfície compreendida entre a Senhora de Mércoles e a capela de Santa Ana, se não a capital dos Tapori, pelo menos um centro urbano secundário, enquanto em São Martinho poderia existir um santuário de alguma forma relacionado com a cidade, que se situaria mais abaixo.

É indubitável, porém, que a resolução deste problema passa pelo incremento de prospecções sistemáticas e escavações científicas nestes e noutros sítios já identificados e que, por isso, exigem uma intervenção. ${ }^{2}$

\section{Formas de identificação e destinos da emigração}

Como já referimos na Introdução, procurámos detectar elementos dos Tapori fora do seu territorio de origem, partindo sempre do princípio de que a indicação da origo significa que o indivíduo é alheio ao local.

O primeiro aspecto a realçar é a forma como essa origem surge na epígrafe. Ela pode surgir de urna forma directa, através da indicação expressa da origo, ou de uma forma indirecta quando na identificação onomástica um antropónimo corresponde a um étnico.

Desta forma, não temos dúvidas quanto à origem dos indivíduos representados pelas inscrições números 16 e 17. Estes indicam, de uma forma indubitável, a origo através do étnico Taporus. Trata-se, provavelmente, de dois cidadãos romanos (o primeiro é-o com certeza) que, morrendo na capital da província da Lusitânia, referem expressamente 
a sua origem indígena. Também na inscrição n. ${ }^{\circ} 23$, um indígena perfeitamente romanizado indica expressamente a sua origo, não deixando dúvidas quanto ao seu território natal. Nas inscrições n. ${ }^{\text {os }} 2,4,5,6,7$, $18,19,21,22$ e 24, temos uma série de indivíduos que se identificam com um nome único a que associam o étnico Taporus. Também na epígrafe $n .^{\circ} 15$, um indivíduo denuncia a sua origem indígena através do étnico Taporus, embora grafado de forma diferente da habitual.

A designação de Taporus pode surgir ainda através do patronímico. Detectámos, assim, cinco indivíduos (inscrições n. ${ }^{\text {os }} 1,9,10,12$ e 20) que denunciam a sua origem indígena, através do patronímico Taporus. Significa isto que quem emigrou foi o pai. A hipótese de se tratar da mesma pessoa coloca-se, em relação às inscrições n.os 9 e 10, uma vez que são provenientes do mesmo local, que à época não seria muito extenso.

Como cognomen, Taporus, surge nas inscrições n.os 11,13 e 14, revelando uma série de indivíduos provenientes desse populus.

Nas epígrafes 3 e 8, Taporus aparece como nome único. Curiosamente, os dois casos correspondem a mulheres que referem apenas este nome e o patronímico.

Devemos ainda prestar atenção ao facto de a designação Taporus aparecer por vezes abreviada, significando isto que seria uma designação por demais conhecida na região. Surge assim, de uma forma abreviada, nas inscrições $n .^{\circ} 2$, de Viseu, e $n .^{\circ} 4$, da Capinha; nestes sítios não seria de estranhar o conhecimento do significado da mesma, dada a proximidade do território dos Tapori dos locais de proveniência destas epígrafes. Mais estranha é a utilização de abreviaturas nas epígrafes n. ${ }^{\circ} 12$, de Tharsis, e n. ${ }^{\circ} 22$, de Santa Eufemia - Córdova. Poderá isto significar a existência de uma grande comunidade de elementos deste populus nestas regiões? Mas, se assim fosse, seria lógico essa origem fazer parte do nome como forma distintiva?

Do conjunto das 24 inscrições, temos 23 epitáfios, apenas uma é votiva, a inscrição n. ${ }^{\circ} 19$, consagrada à deusa Nabia ${ }^{6}$ : trata-se de um indivíduo que prestou culto a esta divindade numa terra que the era alheia.

${ }^{6} \mathrm{Um}$ dos deuses de origem pré-romana venerados ao tempo dos Romanos. Considera José d'Encamação (1990 pp. 447-448) que, sem pormos de parte a hipótese de se tratar de uma divindade particularmente ligada aos benefícios que a água traz à agricultura, lhe devemos também atribuir uma função tutelar. 
Quanto à origem dos Tapori, esta não foi ainda devidamente esclarecida: poderia ser céltica, ibérica ou autóctone. Scarlat Lambrino (1956 p. 65), tendo em conta que os nomes que acompanham Taporus são maioritariamente célticos, como Reburrus, Maelo, Boutius, Celtius, Camalus, e admitindo que os Tapori são iberos - um povo autóctone, anterior aos Celtas - admite que grupos célticos vieram formar o grosso da população desta tribo ou que os Tapori se celtizaram em contacto com invasores vindos da Gália.

Os Tapori encontrar-se-ão, com certeza, entre os povos de origem indoeuropeia, mas pré-céltica (ALARCÃo 1992 p. 344; 1996 p. 26), que se estabeleceram na região da agreste Beira Interior, no Bronze Final. Será, no entanto, precipitado avançar com hipóteses sobre a constituição da população deste populus. No catálogo apresentado, a onomástica indígena predomina, sem dúvida, sobre a latina. Os nomes citados por Scarlat Lambrino estão bem representados. Pensamos, no entanto, que a amostra que constitui este catálogo é reduzida; para tirar conclusões a esse nível seria necessário um estudo mais exaustivo da onomástica da região delimitada como pertencente aos Tapori.

A realização do catálogo epigráfico permitiu trazer alguma luz quanto à dispersão geográfica deste populus. Os destinos da emigração foram variados, desde os territórios vizinhos até paragens fora da própria Lusitânia. E se para alguns destes destinos é possível determinar as motivações para a emigração, para outras é hoje difícil, se não impossível, descobrir as causas que levaram ao abandono da terra natal.

Assim, por exemplo, a emigração para Mérida seria fácil de explicar. Sendo Mérida ${ }^{7}$ capital da Lusitânia, devia reunir uma série de condições como urbanismo e desenvolvimento económico, que funcionariam como atractivos para populações cansadas da rudeza do Interior, à semelhança do que ainda hoje acontece com a saída constante de gente das aldeias para as cidades, onde as oportunidades são maiores.

Em Idanha-a-Velha ${ }^{8}$, cidade capital dos vizinhos Igaeditani, a atracção fundamental seria, para além das suas riquezas agrícolas, os

7 Fundada em 25 a. C., aquando do final das guerras de Augusto no Noroeste (ALARCÃo 1990 p. 350).

8 A fundação desta cidade deve ser considerada na sequência do estabelecimento da colonia Norba Caesarina, deduzida em 35 d. C. (MANTAS 1988 p. 419), sendo certamente uma fundação de Augusto. Existia já em 16 a. C., porque nesta data um cidadão de Emérita Augusta doou à cidade um relógio (AlarCão 1988' p. 35). Esta 
consideráveis recursos mineiros, que também existiam em Tharsis ${ }^{9}$, no Sul de Espanha, e na região de Santa Eufémia, na provincia de Cordova. E sabido que os Romanos foram grandes mineiros na Antiguidade, explorando diversos metais. No actual distrito de Castelo Branco parece ser certa a mineração romana no rio Erges e no Rosmaninhal (junto a Idanha-a-Nova) (Blanco FreIJeIRo 1977 p. 24; Mantas 1988 p. 434), sendo também natural que os vestígios de trabalhos antigos encontrados nos concelhos de Penamacor e Idanha-a-Nova tenham também essa proveniência, principalmente as aluviões dos rios Baságueda, Aravil e Pônsul (AlarCão $1988^{1}$ p. 129; Carvalho e Ferreira 1954 pp. 28-29). E natural que a actividade mineira, nomeadamente a fama do aurifer Tagus e de alguns dos seus afluentes da margem direita, tenha atraído ao território dos Igaeditani e à região de Tharsis populações que, uma vez emigradas, acabaram por se fixar nessas regiões.

Por outro lado, a Beira Baixa e toda a zona nascente das serras da Estrela e da Lapa, terão integrado uma área económica dependente da capital da Lusitânia, servida pela estrada de Mérida à Egitania, bem como pela famosa via da prata que ligava Mérida a Salamanca (ALARCÃo 1990 p. 434). Assim, estas correntes migratórias, como já escreveu Vasco Gil Mantas (1988 p. 436 nota 103), estarão muito relacionadas com os grandes eixos viários regionais e condicionadas por razões económicas e administrativas. Foi a construção de uma rede viária que quebrou o isolamento desta região, facilitando os contactos dos populi que a habitavam com outras áreas da Hispânia.

cidade terá sido promovida ao estatuto municipal sob os Flávios (MANTAS 1988 p. 425), tal como, provavelmente, os Tapori que também tinham os seus cidadãos inscritos na tribo Quirina (situação que a inscrição n. ${ }^{\circ} 16$ comprova).

${ }_{9}$ As minas de Tharsis foram das mais importantes numa extensa faixa piritosa que, de NO para SE, decorre desde Grândola até Asnalcollar (perto de Sevilha). Nesta faixa situam-se também as por demais conhecidas minas de Aljustrel (AlARCÃo 19881 p. 130). 
II. Catálogo

Inscrição $n .^{\circ} 1$

Ach: Conimbriga, Condeixa-a-Nova, Coimbra.

Par: Museu Monográfico de Conimbriga (Inv. n. ${ }^{\circ} \mathrm{A}-188$ ).

Parte direita de urna placa de calcário, reempregue na época visigótica, como o prova o motivo decorativo sobre a parte esquerda actual.

Dimensões: 13,9 x 38,8 (?) x 7,1 cm.

\section{[D(¿LV)]. M\{anibus) / [SVLPICIAE A]MOE/[NAE TAP]ORI (hedera) $\mathrm{F}$ (iliae) / [AHinorum) .... SVJLPICIVS / 5 [RVFVS (?) CONI]VX / $[\mathrm{F}$ (aciendum) $\mid \mathrm{C}$ (uravit)}

Aos deuses Manes. A Sulpicia Amena, filha de Taporo, de ... anos. Sulpicio Rufo (?), o marido, mandou fazer.

ALARCÃO e ÉTIENNE 1976, 37.

A defunta identifica-se, como é regra entre as mulheres romanas, com o gentilicio e o cognomen. O cognomen latino Amoena, a de belo parecer, é um dos que cedo ganha adeptos entre a população indígena (ENCARNAÇÃo 1990 p. 397), sendo característico dos limites da Lusitânia (UNTERMANN 1965 mapa 8 p. 56). O gentilicio parece ser o do marido como sugerem os editores.

Esta inscrição, a estar correcta a reconstituição, denota perfeitamente a aculturação onomástica. A defunta é identificada à maneira romana, não sendo, no entanto, repudiada a sua origem indígena ao indicar-se o patronímico Taporus. Este teria, provavelmente, imigrado para esta região, onde acabou por ficar conhecido por este antropónimo indicativo da origem.

$\mathrm{O}$ dedicante apresenta como cognomen um antropónimo latino bastante comum na Península, identificando-se, aparentemente, apenas com este e o gentilicio, não apresentando praenomen (que se começa a suprimir a partir de finais do séc. II a. C.).

A escrita e o formulário apontam, segundo os editores, para uma datação do séc. II (ALARCÃo e ÉTIENNE 1976 p. 68). 
Inscrição n.. ${ }^{\circ} 2$

Ach: Quinta do Serrado (junto à igreja do Carmo), Santa Maria, Viseu.

Par: Permanece no local do achado.

Placa funerária que se encontrava completa quando do seu aparecimento e hoje apresenta apenas três linhas. De granito, detém uma moldura com sulco e gola reversa, de que resulta um campo epigráfico rebaixado.

MAELO BO/VTI F (ilius) TAP^rws) / ANNO (rum). LX (sexaginta) . $\mathrm{H}(/ \mathrm{c}) / \mathrm{S}($ itus $)$. EOO - S(i'0 . T(ibi) . T\{erra) . LEVIS / 5 FILIO) F(aciendum) . C(uraverunt).

Aqui jaz Melão, filho de Búcio, taporo, de 60 anos. Que a terra te seja leve. Os filhos mandaram fazer.

CIL II, 408; CORTEZ p. 178; ILER 3905; VAZ 1997 pp. 251-252.

A identificação do defunto é feita de acordo com a primeira fase da aculturação onomástica latina: um nome seguido do patronímico, ambos de raiz pré-romana (IRCP p. 776). A própria idade é apresentada arredondada por lustros, como era comum nos epitáfios romanos.

Maelo é um nome lusitano, embora coincidindo com o gentilicio romano Maelius (PALOMAR LAPESA 1957 p. 81, AlBertos 1965 p. 110, UNTERMANN 1965 mapa 52 p. 130$)$.

Quanto ao patronímico Boutius, é um antropónimo tipicamente hispânico, sendo mesmo um dos nomes indígenas mais bem representados, sobretudo na Lusitânia (PALOMAR LAPESA 1957 p. 51, Albertos 1964 p. 231, ABASCAl Palazón 1994 p. 33), como se pode verificar no mapa de distribuição deste antropónimo (UNTERMANN 1965 mapa 18).

Neste epitáfio Taporus está como étnico. Melão, porque morreu fora da sua terra natal, identifica-se também com mais esse elemento acerca da sua origem.

A ausência da consagração aos deuses Manes, o formulário final e o modo da identificação apontam para uma datação de meados do séc. I. 
Inscrição $n .^{\circ} 3$

Ach: Mata da Rainha, Fundão, Castelo Branco.

Par: Museu do Fundão.Bloco de pedra mal aparelhado.

Dimensões: 25 x 58 x 18,2 cm.

TAPORA / TANGINI / F (ilia)H(ic) S E .

Aqui jaz Tapora, filha de Tangino.

VAZ 1977 pp. 20-21; AE 1977, 366.

A defunta é uma indígena: identifica-se com um antropónimo indígena seguido do patronímico também de origem pré-romana. Poder-se-á tratar de alguém com ascendência dos Tapori que, porque nascida fora do território desse populus, recebeu esse nome como forma de distinção.

Tanginus é um nome hispânico, representante típico da área lusitana, pois os que se encontram fora dessa região são muito poucos: cf. AlBERTOS 1965 p. 126, 1972 pp. 313-314; UNTERMANN 1965 mapa 74 pp. 170-171.

João Luís Vaz (1977 p. 25) data a inscrição do séc. I, certamente baseando-se na ausência da invocação aos deuses Manes, na ausência de dedicante, na identificação onomástica e, provavelmente, na paleografia.

Inscrição n. $^{\circ} 4$ (foto)

Ach: Capinha, Fundão, Castelo Branco.

Par: Depositada no jardim do Governo Civil de Castelo Branco.

Trata-se do fragmento irregular de um penedo granítico.

Dimensões: 170 x 118 × $70 \mathrm{~cm}$.

[...] H(ic) . S ${ }_{\text {(itus) }} . \mathrm{E}($ st). S(ít). T(ibi) . Tierra) . L . / MAIELO

CAMALI $¥($ ilius) $\mathrm{T}$ (aporus?) D(e) V(íco) TALABARA FACTVM CVRAVIT PROGELA MAIELONI F(;7 / ET DVTAIVS ARANTONI F (ilius)

Aqui jaz Maielão, filho de Câmalo, Taporo (?) da aldeia de Talabara. Que a terra te seja leve. Tratou de fazer Progela, filha de Maielão, e Dutaio, filho de Arantónio.

CIL II 453; CORTEZ 1952 p. 178; CARVALHO e ENCARNAÇAO 1994. 

Tapori.

Mais uma inscrição da região do Fundão e mais um individuo dos

Os dados que dela constam permitem-nos fazer o seguinte stemma:

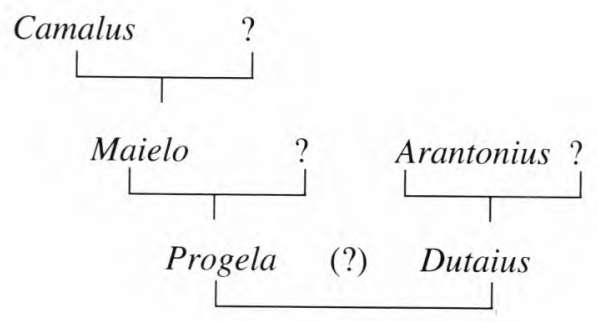

Este epitáfio denota perfeitamente tratar-se de urna familia indígena. Tal como nas duas inscrições anteriores, os indivíduos identificam-se de acordo com a primeira fase da aculturação onomástica latina: um nome seguido do patronímico, ambos de origem pré-romana.

Maielo é urna variante do antropónimo Mailo. A raiz deste nome corresponde à de Maelo (cf. inscr. n. ${ }^{\circ}$ 2), sendo, sem dúvida, a do termo irlandés mael (PALOMAR LAPESA 1957 p. 81, ALBERTOS 1972 p. 298).

O pai do defunto, Camalus, tem um nome hispánico representante típico do reportório luso-galaico (ALBERTOS 1964 p. 235, UnTERMANN 1965 mapa 26 pp. 85-86).

Também neste epitáfio Taporus terá um significado étnico. Será mais um indivíduo pertencente a esse populus que, tendo morrido fora do seu território de origem, é identificado referindo a sua naturalidade étnica. De realçar a referência específica ao vicus Talabara. Este seria um sítio já citado por Ptolomeu e desse topónimo antigo teriam derivado as diversas Talaveras hoje existentes em território espanhol (CARVALHO e ENCARNAÇÃo 1994 p. 49). O cuidado em identificar a naturalidade do defunto faz-nos deduzir que o referido vicus não pode identificar-se com a Capinha. Por outro lado, poderemos concluir que Talabara se situaria no território dos Tapori.

Os dedicantes são a filha e, muito provavelmente, o marido desta. Este identifica-se com um antropónimo hispânico característico da área lusitanogalega (UnTERMAnN 1965 mapa 39 p. 108), Dutaius. Já o nome Progela parece ser até ao momento o único testemunho conhecido: será, decerto, corruptela local do nome latino Procella, esse sim documentado (CARVALHO e ENCARNAÇÃo 1994 p. 48).

O pai de Dutaius apresenta um nome, Arantonius, característico da região da Beira Interior, nomeadamente de Idanha (Egitânia 1, 52, 53, 65; ALBERTOS 1976 p. 74). 
Sobre esta inscrição recaem ainda dúvidas se o texto, tanto na primeira como na última linha, está ou não incompleto. Na realidade, o texto inicia-se por fórmulas funerárias que, de ordinário, não encabeçam os epitáfios. No entanto, como referem Rogério Carvalho e José d'Encarnação (1994 p. 48), começar a inscrição pela fórmula que é hábito vir no fimm não é de estranharmos se a considerarmos dos primórdios do Império, quiçá mesmo da primeira metade do séc. I da nossa era. Esta hipótese é corroborada pela paleografia, pelo modo de identificação das personagens, bem como pela sua onomástica tipicamente de origem pré-romana. Por outro lado, estranhar-se-á o abuso dos nexos numa inscrição do séc. I; contudo, há que ter em conta que o suporte epigráfico é uma rocha, onde são maiores as dificuldades de gravação e a paginação obedece somente à superfície lisa disponível.

Inscrição $n .^{\circ} 5$

Ach: Mós do Douro, Vila Nova de Foz Coa, Guarda.

Par: Numa horta de Amílcar Moutinho, no sítio da Cruzinha, servindo de esteio numa latada.

Bloco de lousa característica de um local distanciado poucos quilómetros a sudeste. Originariamente, terá sido uma esteia funerária, encontrando-se fracturada do lado esquerdo, no sentido da vertical.

Dimensões: 165 (?) x 28 (?) x 8,5 cm (encontra-se parcialmente enterrada, daí a dificuldade em determinar a altura exacta).

[AL]BINVS / [A]PILI . F(ilius) / [TA]PORVS / [A]N(norum) XL (<quadraginta) $/ 5$ [H(/c)] S (itus) E (st) / [T]VREA / [A]LBONI . F (ilia) / [V]XOR . B(ene)M(erenti) / [F(aciendum) .] C(uravit) . S(it) . T(ibi) . T(erra) . L(evis) .

Aqui jaz Albino, filho de Apilo, Taporo, de 40 anos. A mulher, Túrea, filha de Albónio, merecidamente, mandou fazer. Que a terra te seja leve.

\section{CURADO 1985.}

Fernando Patrício Curado coloca também a hipótese de se reconstituir Coporus em vez de Taporus, por existirem dois indivíduos em Lamego com esta denominação. A dúvida mantém-se, apesar de nos parecer mais provável Taporus, uma vez que são mais numerosos os exemplos deste.

O defunto identifica-se já com um antropónimo latino -Albinus - muito frequente na Hispânia (ALBERTOS 1964 p. 217; UNTERMANN 1965 mapa 4 pp. 47-48). A este nome acrescenta, na identificação, a sua origem étnica dos 
Tapori, que Femando Patricio Curado considerou, erradamente, pois Albinus não é gentilicio, ser cognomen. O pai, Apilus, tem um nome indígena que se localiza essencialmente a norte do Douro (ALBERTOS 1976 p. 74).

A esposa que, saudosamente, lhe dedica o monumento, identifica-se com o antropónimo indígena Turea (UNTERMANN 1965 mapa 78 pp. 177-178) e com o patronímico Albonius, antropónimo também hispânico que cobre essencialmente a área da Lusitânia romana (ALBERTOs 1976 p. 71; UnTERMANN 1965 mapa 5 pp. 49-50).

Este epitáfio permite determinar os seguintes laços familiares:

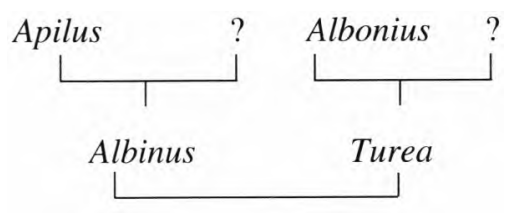

$\mathrm{Na}$ inscrição está presente um elogio - ao marido merecedor - que era comum nos epitáfios romanos. Elogio que se faz, muitas vezes, não por sinceridade, mas por medo e respeito pelo morto (cf. IRCP pp. 818-820), sentimento em que também se enquadra o desejo de que "a terra te seja leve".

Pela paleografia, Fernando Patrício Curado data o monumento de finais do séc. I.

\section{Inscrição $n .^{\circ} 6$}

Ach: Póvoa do Mileu, Guarda.

Par: Museu da Guarda (n. $\left.{ }^{\circ} 687\right)$.

Lápide funerária, da qual não se dispõe de qualquer descrição, além das dimensões.

Dimensões: 80 x 44 x (?) cm

D(iis) M(anibus) S(aerum) / FRONTONI LA/VRI F(ilio) . TAPORO A/NNORVM LXV (sexaginta quinque) QVIN/5TA TELCI LI[BE]RTA MARI/TO PlENTIS(simo) F(aciendum) . C(uravit) .

Consagrado aos deuses Manes. A Frontão, filho de Lauro, Taporo, de 65 anos. Quinta, liberta de Telco, mandou fazer ao marido, modelo de piedade.

HAEp. 1950-1952 412; CORTEZ 1952 p. 177; RODRIGUES 1957-1958; RODRIGUES 1962; HAEp. 1961-1965 2025; ILER 4577. 


\section{Variantes: 1. 4, 5 e 6: NNORVM LXV OVIN/TA TEISI LI[BER]TA NOVALA) / ORIENTIS I(ussit) F(aciendum) C(uravit) (CORTEZ e HAEp. 1950-1952) \\ 1. 6: TO PIENTIS[SIMO] P(onendum) C(uravit) (HAEp. 1961-1965)}

Esta inscrição apresenta algumas dúvidas de leitura. Resolvemos optar pela de Adriano Vasco Rodrigues e do ILER, por nos parecer a mais correcta. Optámos ainda pelos antropónimos Quinta e Telcus em vez de Ovinta e Teisus, uma vez que estes nomes não se encontram registados (ALBERTOS 1965 pp. 116 e 127).

O defunto identifica-se, pois, com o nome latino Fronto (KAJANTO 1982 pp. 17, 26, 118 e 236) a que se juntou o etnónimo Taporo.

A esposa, que apresenta nome latino que habitualmente é praenomen, identifica-se como liberta, demonstrando assim orgulho pelo seu patrono Telcus, com certeza alguém importante na região.

A invocação aos deuses Manes, que se faz utilizando apenas as siglas $D M S$, e o uso do adjectivo sugerem os finais do séc. II.

Inscrição n. $^{\circ} 7$ (foto)

Ach: Idanha-a-Velha, Idanha-a-Nova, Castelo Branco.

Par: Idanha-a-Velha.

Estela de topo arredondado, de granito.

Dimensões: 55 x 41 x $16 \mathrm{~cm}$

[APO ?]NIVS / [CjELTI. F(ilius) / [TJAPORVS / [...JAREO (?) /[...]

Apónio (?), filho de Céltio, Taporo ...

Egitânia 59; HAEp. 1955-1956 1109; LAMBRINO 195620.

O defunto identifica-se com um nome único e o étnico Taporus. $\mathbf{O}$ nome foi reconstruído como sendo Aponius, mas, de facto, também pode ser Anius, o que até parece mais correcto tendo em conta o espaço, onde deverá caber apenas uma letra como nas linhas posteriores.

O pai tem um nome, Celtius, que se encontra com frequência na região lusitana (ALBERTOS 1976 p. 78; UNTERMANN 1965 mapa 34 pp. 98-99).

Provavelmente, nas linhas em que a leitura é impossível, devido à fra- 
gmentação do monumento na sua parte inferior, estaña a identificação do dedicante e a fórmula final HSESTTL.

Pese embora as limitações provocadas pelo facto de o texto estar incompleto e não ser possível uma análise paleográfica, ousaríamos, dada a ausência da invocação aos deuses Manes e a própria simplicidade textual, datar o epitáfio do séc. I.

Inscrição $n .^{\circ} 8$ (foto)

Ach: Idanha-a-Velha, Idanha-a-Nova, Castelo Branco.

Par: Idanha-a-Velha.

Esteia de granito, moldurada.

Dimensões: $100 \times 37$ × $32 \mathrm{~cm}$

[D(iis) $\mathrm{M}$ (anibus)] S(aerum) / TAPOR/A . LEVRI (filia) / LANTV/5TRA CAT/VRONIS (filia)

Consagrado aos deuses Manes. Tapora, filha de Leuro. Lantutra, filha de Caturo.

Egitânia 131; HAEp. 1955-1956 1170; LAMBRINO 1956 43; AE 1967 180; ILER 6091.

Variantes: 1. 4-5: IANTV/TRA (LAMBRINO)

LANTVRA (AE, ILER)

Mais duas indígenas que se idenficam apenas com um nome e o patronímico.

Tapora apresenta o patronímico Leurus, que é nome latino (ALBERTos 1972 p. 295).

Lantutra é um antropónimo do qual se conhece, até ao momento, apenas este exemplo. O pai, Caturo, tem um nome bem atestado em várias regiões da Hispânia, sendo um representante típico da área luso-galaica (ALBERTOS 1964 p. 238; UNTERMANN 1965 mapa 33 pp. 96-97).

Entre as defuntas, e porque têm um epitáfio em comum, existiria uma relação, provavelmente de parentesco, mas difícil de determinar uma vez que o pai não é o mesmo. Não obstante, podemos também colocar a hipótese de a segunda personagem ser a dedicante.

A invocação aos deuses Manes aliada à simplicidade textual induz-nos a datar o epitáfio de finais do séc. I. 
Inscrição n. ${ }^{\circ} 9$ (foto)

Ach: S. Pedro do Corval, Reguengos de Monsaraz, Évora.

Par: Museu de Évora. N. ${ }^{\circ} 1890$.

Estela funerária de ardósia, que se encontra partida do lado esquerdo, e com frontão marcado em altura através de sulcos na superficie frontal, onde se notam as linhas auxiliares.

Dimensões: 89 × 66 × $5 \mathrm{~cm}$

[praenomen] [C]ASSIVS . RVFV[S] / [TAP]ORI (?) . F(Mus) . $\mathrm{AN}$ (riorum) . XXXV (triginta quinque) / [ ]CI FC . X CE . ) ?/ [ . . ] H(/c) $\mathrm{S}$ (itus) $[\mathrm{E}(\mathrm{si})] / 5$ [..?]

Aqui jaz ... Cássio Rufo, filho de Taporo, de 35 anos ...

ENCARNAÇÃO 1982; AE 1982 462; IRCP 417.

Esta epígrafe faz referência a um indivíduo que se identifica com os tria nomina, seguidos do patronímico Taporus. O defunto é membro da gens Cassia, de que existem outros exemplos na Península, nomeadamente no conventus Pacensis (IRCP p. 496). O cognome latino Rufus é comum, sendo mesmo um dos mais frequentes na Península (ABASCAL PALAZÓN 1994 p. 31).

A identificação através dos tria nomina denuncia a perfeita aculturação onomástica deste indivíduo. Apesar disso, ao ser feito o epitáfio, não foi repudiada a sua origem indígena ao ser indicada a filiação.

A ausência da invocação aos deuses Manes e a paleografia (caracteres actuários) levam-nos a datar a inscrição do séc. I.

Inscrição $n .^{\circ} 10$ (foto)

Ach: Numa necrópole junto de S. Pedro do Corval, Reguengos de Monsaraz, Évora.

Par: Museu de Évora. N. ${ }^{\circ} 1724$.

Esteia funerária de ardósia da região, em forma de tampa de sepultura.

Dimensões: 17,6 x 58,5 x $4 \mathrm{~cm}$

C(aius) IVLIVS . PRO/CVLVS . TAPO/RI . F (ilius) AN (norum) . XX (viginti) / $\mathrm{H}(/ \mathrm{c}) . \mathrm{S}($ itus $) . \mathrm{E}($ st) . CVR(avit) / PATER 
Aqui jaz Gaio Júlio Próculo, filho de Taporo, de 20 anos. O pai mandou fazer.

CIL II 6263; ILER 4156; IRCP 424.

Variantes: 1. 2: AÑ $\sim(\mathrm{CIL})$

Tal como na inscrição anterior, o defunto identifica-se com os tria nomina, seguidos do patronímico indígena Taporus, o que denota urna romanização de fresca data. A adopção dos nomes Caius lulius indiciam uma influência do reinado dos primeiros imperadores (IRCP p. 502). Aliás, o nomen lulius tem uma posição privilegiada na frequência dos nomina na Hispânia. Como gentilicio imperial, a sua difusão foi extraordinária nas regiões que se incorporaram na latinidade entre César e os Flávios, alcançando um número que nenhum outro conseguiria (ABASCAL PALAZÓN 1994 p. 29). Esta repetição explica-se pela enorme popularidade de que gozaram alguns gentilicios e nomes próprios: na ausência de um referente familiar ou de patrono, serviam para acompanhar as mudanças da situação jurídica pessoal (ABASCAL PALAZÓN 1994 p. 30).

Quanto ao cognomen Proculus é tipicamente latino.

José d'Encarnação (IRCP p. 502) coloca a hipótese de o defunto desta inscrição e da anterior serem irmãos que assumiram tria nomina diferentes.

A referência da idade, arredondada por lustros, como era comum, terá aqui, com certeza, um valor sentimental: a morte precoce deste jovem terá acrescido a dor provocada aos seus entes queridos.

Tendo em conta a descrição paleográfica (capitais actuárias) e a própria identificação onomástica, consideramos a inscrição da segunda metade do séc. I.

Inscrição . $^{\circ} 11$

Ach: Termo de Marvão, Marvão, Portalegre.

Par: Museu de Marvão.

Fragmento de uma epígrafe de tipología indefinida, de granito.

Dimensões: 29 × $110 \times 10,5 \mathrm{~cm}$

$[\ldots] /[\ldots]$ NIO. TAPORO

HAEp. 1961-1965 2139; PAÇO e ALMEIDA 1962 pp. 149-150; AE 1963 147; ILER 932; IRCP 636.

Variantes: 1. 2: [...]ANO (PAÇO e ALMEIDA; ILER) 
O texto está muito mal conservado, pelo que se toma bastante difícil a sua interpretação.

Nesta inscrição apenas podemos considerar a terminação de um nome e, provavelmente, o cognomen Taporus.

Os caracteres são do séc. I (PAÇO e ALMEIDA 1962 p. 149).

Inscrição $n .^{\circ} 12$

Ach: Tharsis, Huelva.

Par: (?)

Não se dispõe de qualquer descrição do monumento.

CAMA[L]VS TA[P(ori)] F(ilius) [...?]

Câmalo, filho de Taporo, ...

HAEp. 2355.

Este indígena identifica-se de acordo com a primeira fase da aculturação onomástica latina.

Camalus é um nome hispánico, representante típico do reportório lusogalaico (ALBERTOS 1964 p. 235; UNTERMANN 1965 mapa 26 pp. 85-86).

A simplicidade na forma de identificação, acrescida da ausência de invocação aos deuses Manes, induz-nos a datar a inscrição da primeira metade do séc. I.

Inscrição n. ${ }^{\circ} 13$

Ach: No Mosteiro de San Augustin, Badajoz.

Par: Permanece no local do achado.

Tábua de mármore.

[CORNjELIAE . HY[G]IAE / [IVLI?]VS . TAPORVS / [MAT]RI . OPTIMAE / [DVL]CISSIMAE / 5 [AM] ANTIS SIMAE

A Cornélia Hígia. Julio Taporo à mãe óptima, querida e muito amada.

CIL II 1018; ILER 4041. 
A defunta identifica-se como pertencente à gens Cornelia e com o cognomen Hygia. O facto de apresentar um cognomen de origem grega e omitir a filiação indicia o seu antigo estatuto de escrava.

$\mathrm{O}$ gentilicio, adquirido com a liberdade, está muito bem representado na Península (ABASCAL PALAZÓN 1994 p. 30).

O dedicante identifica-se, provavelmente, com o gentilicio Iulius (cf. insc. n. ${ }^{\circ}$ 10) e o cognomen indígena Taporus. Parece verificar-se a ausência do praenomen.

A dor deste filho pela morte da mãe está bem patente na utilização de superlativos para enaltecer as qualidades da defunta.

A ausência de praenomen e a utilização de superlativos como qualificativos da defunta sugerem-nos, como cronologia, os finais do séc. II.

Inscrição n. ${ }^{\circ} 14$

Ach: Mérida, Badajoz.

Par: (?)

Não se dispõe de qualquer descrição do monumento.

PAPIRIA M\{́arei). L(iberta) . TAPORA

Papiria Tapora, liberta de Marco.

AE 1971145.

Tapora, nesta inscrição, surge como cognomen da defunta. O seu gentilicio, Papiria, adquiriu-o, provavelmente, do seu patrono. Esta situação deve-se ao facto de ser uma antiga escrava que alcançou a liberdade.

A simplicidade textual aponta para o séc. I.

Inscrição n. ${ }^{\circ} 15$

Ach: Mérida, Badajoz.

Par: (?)

Ara de mármore branco.

Dimensões: 20 × $8 \mathrm{~cm}$

[...] [P]ATRICIA / [...] H(/c) . S (ita) . E (st) . S (it) . T(ibi) . T (erra) . L(evis) / [AJNNIA PRISCA / [MAT]RI ET TVTILIV/5S TAPORIO . VXORI / INCOMPARABILI F(aciendum). C(uraverunt) . 
Aquí jaz Patricia .... Que a terra te seja leve. Ânia Prisca, à mãe, e Tutílio, Taporião, à esposa incomparável, mandaram fazer.

HAEp. 1953-1954 692; ILER 3667.

A defunta identifica-se com o nomen Patricia e um cognomen que, com certeza, estaría no inicio da segunda linha. Tem como dedicantes do seu epitáfio a filha e o marido. A filha pertence à gens Annia, de que há vários exemplos na Península (cf. IRCP), e tem o cognomen latino Prisca.

A onomástica patente na epígrafe é latina, denunciando já um elevado grau de romanização.

Interessante é verificar a presença do étnico Taporio em ablativo, como é normal tratando-se da origo. Se surgisse como cognomen, estaría em nominativo de forma a concordar com Tutilius. Porém, pode estar grafado Taporio no nominativo e não Taporas, como é habitual. Desta sorte, estamos em presença de mais um elemento deste populus que acabou por constituir famñia longe da sua terra natal.

$\mathrm{O}$ facto de a defunta e o marido omitirem a filiação leva-nos a colocar a hipótese de estarmos em presença de um casal de libertos não pertencentes à mesma gens.

A onomástica latina e o uso do adjectivo sugerem uma datação de finais do séc. II para este epitáfio.

Inscrição n. ${ }^{\circ} 16$

Ach: Mérida, Badajoz.

Par: Em casa do Conde de la Roca Moreno (segundo Hlibner).

Não se dispõe de qualquer descrição do monumento.

D(iis). M\{anibus). S(acrum). / L(ucio). IVLIO LONGINO / QWlR(ina tribu). TAPORO / ANN(<9rum) XXXV (triginta quinque) $/{ }^{5} \mathrm{~L}$ (ucius) IVLIVS AVITVS / FILIO PIISSIMO

Consagrado aos deuses Manes. A Lúcio Júlio Longino, da tribo Quirina, taporo, de 35 anos. Lúcio Júlio Avito ao filho, modelo de piedade.

CIL II 519; CORTEZ 1952 p. 178; ILER 4176.

Variantes: 1. 4: ANN XXV (CORTEZ)

Conimbriga, 39 (2000) 153-189 
O homenageado identifica-se como cidadão romano inscrito na tribo Quirina, cuja atribuição R. Étienne e G. Fabre (1972 pp. 200-203) consideram ser apanágio dos Flávios. Esta referência explícita à tribo denuncia um cidadão de fresca data, até pelo facto de a tribo vir mencionada após o cognomen.

Este orgulhoso cidadão romano apresenta os tria nomina, pertencendo à numerosa gens Iulia (cf. insc. n. ${ }^{\circ} 10 \mathrm{e} \mathrm{13).} \mathrm{O}$ cognomen Longinus é latino.

O seu pai, que se identifica também com os tria nomina, denota igualmente a perfeita aculturação onomástica romana. O cognomen Avitus é um nome latino que cedo ganhou as boas graças da população (ENCARNAÇ̃̃o 1990 p. 397), sendo por isso muito frequente nas inscrições hispânicas (ALBERTOS 1964 p. 227). a origo.

Nesta epígrafe, Taporo tem um valor étnico indubitável: representa

Mais um epitáfio onde o defunto é elogiado, e, neste caso, dado o grau de parentesco e a idade da morte, denuncia um sentimento de saudade e pesar sincero, mais que um simples elogio por superstição.

A consagração aos deuses Manes e o uso do superlativo indiciam uma datação do séc. II.

Inscrição $n .^{\circ} 17$

Ach: Mérida, Badajoz.

Par: (?)

Cipo, encontrado em 1608.

D (iis) M(anibus) S (acrum) / MARCO RVFINO ALBINO / TAPORO ANN( o rum) XXV (viginti quinque) / FLAVIA FLAVINA / 5 MATER ET FLORIA SEVERA / VXOR / F(aciendum) C(uraverunt)

Consagrado aos deuses Manes. A Marco Rufino Albino, taporo, de 25 anos. A mãe, Flávia Flavina, e a esposa, Flória Severa, mandaram fazer.

CIL II 521; ILER 3670.

\section{Variantes: 1. 4: FLAVIA FLA VINCA (ILER)}

O defunto identifica-se com o praenomen e dois cognomina, a não ser que haja uma leitura incorrecta de Rufino, podendo tratar-se do nomen Rufinio. Contudo, são admissíveis os dois cognomina para quem entrou recentemente no esquema identificativo romano, e por isso é referido o praenomen por extenso e não apenas a sigla como é usual. 
Também aqui temos a presença indubitável do étnico Taporo.

As dedicantes, a mãe e a esposa, identificam-se da forma normal entre as mulheres romanas: com o gentilicio e o cognomen.

Toda a onomástica patente no epitáfio é latina, indiciando um elevado grau de romanização.

Tendo em conta a invocação aos deuses Manes e o esquema identificativo, apontamos para uma datação da segunda metade do séc. I.

Inscrição . $^{\circ} 18$

Ach: Mérida, Badajoz.

Par: (?)

Não se dispõe de qualquer descrição do monumento, apenas se sabe que foi encontrado em 1607.

LVPVS / ALBIN(Í) . F (ilius) . / TAPOR/VS . AN (norum) . L (quinquaginta) $/ 5 \mathrm{H}$ (ic). S (itus) . E (st) . S (it) . T (ibi) . T (erra). L (evis)

Aqui jaz Lupo, filho de Albino, taporo, de 50 anos. Que a terra te seja leve.

CIL II 520; CORTEZ 1952 p. 178; ILER 2744.

Variantes: 1. 4: IS . AN. L (CIL II)

Este indivíduo de nome Lupus denuncia a sua origem indígena, associando ao seu nome, provavelmente latino (ALBERTOS 1972 p. 298; KAJANTO 1982 p. 85), o etnónimo Taporus. Na Lusitânia, é em Mérida que o cognome Lupus aparece com mais frequência nos textos epigráficos onde se associa a gentilicios romanos e a nomes indígenas (DIAS 1979 p. 212).

Neste epitáfio, Taporus sugere mais um elemento deste populus. $\mathrm{Ou}$ estando correcta a leitura do CIL - Taporis "dos Taporos" - teríamos mais um ablativo no plural, esse sim indicativo étnico indubitável.

A ausência da invocação aos deuses Manes e a simplicidade textual induzem a uma datação do séc. I. 
Inscrição n. ${ }^{\circ} 19$

Ach: San Juan, Villa del Rey (Brozas), Cáceres. Mas, como sofreu deslocações desde o seu emprego original à sua utilização como silhar, a ara pode vir de Villa Vieja de Alcántara, situada entre o Tejo e o Jartín, como outras (MELENA 1984 p. 260).

Par: (?)

Ara que foi trabalhada e convertida em silhar.

[...] MAXVM/[V]S . VLAT/[I]CI . F\{ilius) . TA/[P]ORVS . / 5 [N]A$\mathrm{BIAE} /[\mathrm{S}] \mathrm{ACRVM}$

(...) Máxumo, filho de Ulático, taporo. Consagrado a Nábia.

MELENA 1984 pp. 259-260; AE 1984496.

Ara dedicada a Nábia, sem dúvida a divindade feminina indígena mais importante do NO hispánico.

Tal como na inscrição anterior, temos um individuo que denuncia a sua origem indígena associando ao cognomen latino Maxumus o etnónimo Tap o rus.

Inscrição n. ${ }^{\circ} 20$

Ach: San Martin de Castañar (na estrada de Ciudad Rodrigo a Bejar), Salamanca.

Par: (?)

Não se dispõe de qualquer descrição do monumento.

BOLOSEA / BREVI(/) . F\{ilia) . VIX(ií) / AN(nis) . LXX (septuaginta) . H (ic) . S (ita) . E (st) / S (it) . T(ibi) . T (erra) . L(evis) . / 5 REBVRRVS / TAPORI. F(ilius) . CE/NTVRIO / MATRI

Aqui jaz Bolosea, filha de Brévio. Viveu 70 anos. Que a terra te seja leve. $\mathrm{O}$ centurião Reburro, filho de Taporo, à mãe.

CIL II 881; HAEp. 413; CORTEZ 1952 pp. 177-178; ILER 3977.

Considerando os parentescos indicados, podemos estabelecer o seguinte stemma:

Conimbriga, 39 (2000) 153-189 
Brevius

Bolosea Taporus

Reburrus

A defunta tem um nome pouco frequente, Bolosea, atestado apenas mais duas vezes em Idanha e outra em Caparra (PALOMAR LAPESA 1957 p. 49; ALBERTOS 1964 p. 230).

O pai da defunta apresenta também um antropónimo, Brevius, atestado somente em Idanha (ALBERTOS 1964 p. 231).

Reburrus, ao invés, é antropónimo indígena que domina essencialmente na área lusitano-galega (UNTERMANN 1965 mapa 66 pp. 155-156).

Neste epitáfio temos mais um exemplo em que o antropónimo indígena Taporus surge como patronímico (cf. insc. n.os 1, 2, 9, 10 e 12).

$M^{a}$ de Lourdes Albertos (1965 p. 126) coloca a hipótese de este Taporus ser lusitano, quiçá de Idanha, porque é o pai de um centurião romano, Reburrus, cuja mãe e avô materno, Bolosea e Brevius, têm nomes atestados também em Idanha e são completamente estranhos ao conjunto da antroponímia da província de Salamanca. Na nossa opinião, esta hipótese não nos parece muito viável, pois se ela se poderia colocar em relação a Bolosea, Brevius e Reburrus, parece ser pouco provável em relação a Taporus. Ele, na realidade, deveria ser da Lusitânia, e até poderemos supor que terá vivido em Idanha, onde constituiu família; no entanto, a designação de Taporus leva-nos a remetê-lo para o território do povo com o mesmo nome, sendo ponto assente que a Idanha corresponde o povo dos Igaeditani.

A ausência de invocação aos deuses Manes e a própria simplicidade na identificação onomástica sugerem o séc. I.

\section{Inscrição n. ${ }^{\circ} 21$}

Ach: Numa necrópole do lugar de "Minas Viejas", Santa Eufemia, Almadén, Córdoba.

Par: Encontra-se junto de uma figueira, num poço aproximadamente a 100 m da estrada 411, entre Santa Eufemia e Almadén.

Estela de arenito local com remate semicircular, fragmentada na parte inferior. Na parte superior apresenta um crescente lunar.

Dimensões: 73 × 50 × $25 \mathrm{~cm}$

ARANTONI/VS CILI F(ilius) / [T]APORV[S] /[...] 
Arantónio, filho de Cilio, taporo, ...

STYLOW 1986 1; HEp. 1989296.

O defunto identifica-se com o antropónimo Arantonius, caracte-rístico da região de Idanha (cf. insc. n. $^{\circ} 4$ ). Taporus é aqui empregue inequivocamente como origo.

Este Arantonius estada, decerto, entre os muitos homens que trabalhariam como mineiros na Betúria túrdula, rica em minas de chumbo. A necrópole, onde este epitáfio foi encontrado, seria da colonia mineira (HEp.).

O patronímico Cilius é um nome hispânico bem conhecido, nomeadamente na área lusitano-galega (PALOMAR LAPESA 1957 p. 64; ALBERTOS 1964 p. 240; UNTERMANN 1965 mapa 35 pp. 20, 100-101; ALBERTOS 1972 p. 27; Albertos 1976 p. 79).

A inscrição pode datar-se de fins do séc. I (HEp.).

Inscrição n. $^{\circ} 22$

Ach: Numa necrópole do lugar de "Minas Viejas", Santa Eufemia, Almadén, Córdoba.

Par: Encontra-se no sítio do achado, num campo a $150 \mathrm{~m}$ a sudoeste da estrada 411, entre Santa Eufemia e Almadén (informação em HEp.).

Estela de arenito local, de remate triangular com um motivo semiesférico no centro.

Dimensões: 120 x 47 x $27 \mathrm{~cm}$

LVPVS CA/MALI (filius) TAP (orus) / ANN (orum) XX/XV (triginta quinque) $\mathrm{H}(/ \mathrm{c}) \mathrm{S}$ (itus) E (st) / ${ }^{5} \mathrm{~T}(\mathrm{e}) \mathrm{R}($ ogo $) \mathrm{P}$ (raeteriens) D (icas) S (it) / T (ibi) $\mathrm{T}$ (erra) L(evis)

Aqui jaz Lupo, filho de Câmalo, taporo, de 35 anos. Rogo-te, ó passante, que digas: "A terra te seja leve".

STYLOW 1986 2; HEp. 1989297.

Este epitáfio provém do mesmo local do anterior, denunciando, portanto, mais um indivíduo que teria emigrado para a região, a fim de trabalhar nas minas. Trata-se de mais um Lupus, que denuncia a sua origem indígena associando a este nome latino o indígena Taporus (cf. insc. n. ${ }^{\circ} 18$ ). Também aqui Taporus terá um valor étnico e o facto de estar abreviado pode indiciar a existência de outros elementos deste populus no local. 
O pai apresenta o nome hispánico Camalus, que já nos surgiu nas inscrições 4 e 12. Destaca-se, no entanto, a n. ${ }^{\circ}$ 4: epitáfio de "Melão, filho de Câmalo, taporo". Apesar da fragilidade da hipótese, pensamos não ser de todo inadvertido questionar da possibilidade de Maielo e Lupus serem irmãos.

A fórmula final denota um conhecimento dos modelos romanos. Este formulário enquadra-se no diálogo dos mortos com os vivos, na necessidade de o morto continuar a partilhar o mundo dos vivos (cf. FerReIRA 1996).

Pela filiação subentendida, o formulário final e a forma das letras, data-se da primeira metade do séc. I (HEp.; STYLow 1986 p. 245).

Inscrição n. ${ }^{\circ} 23$

Ach: Córdoba.

Par: Museu Nacional de Arqueologia de Espanha. N. ${ }^{\circ} 16834$.

Placa de mármore fragmentada na parte superior, inferior e do lado direito. O campo epigráfico foi moldurado com decoração vegetal.

Dimensões: 20,5 (?) x 27 (?) x $6 \mathrm{~cm}$

$\mathrm{D}$ (iiis) [M(anibus) $\mathrm{S}$ (acrum)] / C(aius) VAL(erius) AVITVS [...] / NATIONE TA[PORVS ?] / GEMMA QVOD EST A[...] / 5 QVOD

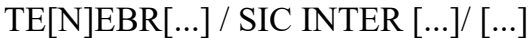

Consagrado aos deuses Manes. Caio Valério Avito, da nação dos $T a-$ pori (?)...

CILII 2253; HEp. 1993163.

Variantes: 1. 4, 5, 6: GEMNA QVOD EST M[...]/ QVODIE FEBRV[ARII] [MEN]/SIS INTER K[ALARI] [...] (CIL II)

O defunto é um indivíduo perfeitamente romanizado que se identifica com os tria nomina. $\mathrm{O}$ cognomen é latino (cf. insc. $\mathrm{n}^{\circ}{ }^{\circ}$ 16) e o gentilicio, um dos mais comuns na Península (ABASCAL PALAzón 1994 p. 30).

Já se chamou a atenção para o conceito de natio, que parece mais ampio que o de um populus lusitano como os Tapori (HEp.). Não nos parece, no entanto, um argumento válido, pois na base do conceito de nação está essencialmente uma comunhão de cultura e tradições que faz com que um conjunto de indivíduos se sintam unidos por uma mesma identidade.

A inscrição poder-se-á datar de fins do séc. II ou princípios do III (HEp.).

Conimbriga, 39 (2000) 153-189 
Inscrição n. ${ }^{\circ} 24$

Ach: Inscrição lusitana de origem incerta.

Par: (?)

Não se dispõe de qualquer descrição do monumento.

MARCIA S M / RIC . EF . AN (riorum) LX (sexaginta) / H (ic) . S (itá) . E(st). S(it). T(ibi). T(erra). L(evis) / ALBINVS /5 ET [...]/S FLAVS . FL/A . CO FILI / MATRI . F(aciendum) . C(uraveruni) / ALBINVS / TAPORVS [...] L/ANCIEN/10SIS . P(atri). M(atri). F(aciendum) . C(uravit)

Aqui jaz Márcia, ..., de 60 anos. Que a terra te seja leve. Albino e ..., Flau, Flaco, os filhos, mandaram fazer à mãe. Albino, taporo, ..., dos Lancienses, mandou fazer ao pai e à mãe.

CIL II 950; CORTEZ 1952 p. 178; ILER 5361; CPIL 131.

Variantes: 1. 1: MRCIA (CORTEZ)

1. 9: ISANGLIN (CORTEZ)

O texto apresenta-se assaz confuso, pelo que a interpretação que dele se faz mantém fortes reservas.

A defunta seria um elemento da gens Mareia, gens numerosa na Península. No final da primeira linha e início da segunda poderá estar o cognomen.

Os dedicantes seriam os filhos, que apresentam onomástica latina: Albinus, nome muito frequente na Hispânia (ALBERTos 1964 p. 217), Flaus, nome também latino de boa adaptação entre os indígenas (ABASCal Palazón 1994 p. 31) e ainda Flacco (que deveria estar grafado Flaccus). Temos ainda um outro personagem que se identifica como "Albino Taporo" e que não sabemos se será o mesmo citado na quarta linha da inscrição. 


\section{Bibliografía*}

Abascal Palazón (Juan Manuel), Los Nombres Personales en las Inscripciones Latinas de Hispania, Murcia, 1994.

AlarCão (Jorge), O Dominio Romano em Portugal, Lisboa, 1988 (= AlarCão 1988')-

- "Os Montes Herminios e os Lusitanos", Livro de Homenagem a Orlando Ribeiro, Lisboa, 1988, vol. 2, pp. 41-48 (= ALARCÃo 19882).

- Roman Portugal,vol II, Fase. 1, 1988 (=Alarcão 1988³). (coord.), Nova Historia de Portugal, vol. I, Lisboa, 1990, pp. 352-441.

- "Etnografía da fachada atlântica ocidental da Península Ibérica", in ALMAGRO - Gorbea e Ruiz ZAPATERo (eds. ), Paleoetnologia de la Peninsula Complutum, 2-3, 1992, pp. 339-345.

— "O primeiro milénio a. C.", De Ulisses a Viriato, o primeiro milénio a. C., 1996, pp. 15-30.

AlarCão (Jorge) e ÉtienNe (Robert) (dir.), Fouilles de Conimbriga, II, Paris, 1976.

— "Le Portugal à 1'époque augustéene", Symposium de Ciudades Augusteas, Saragoça, 1976, pp. 171-187.

AlarCão (Jorge) e IMPERIAL (Flávio), "Sobre a localização dos Lancienses e Tapori”,

Miscellanea em Homenagem ao Professor Bairrão Oleiro, Lisboa, 1996, pp. 39-44.

ALBERTOS (Maria de Lourdes), "Nuevos antropónimos hispánicos", Emerita, tomo

XXXII, fase. $2 .^{\circ}$, Madrid, 1964, pp. 209-252; tomo XXXIII, fase. . $^{\circ}, 1965$,

pp. 109-143; tomo XL, fase. $1 .^{\circ}, 1972$, pp. $1-29$; tomo XL, fase. $2 .^{\circ}, 1972$,

pp. 287-318.

- "La antroponimia prerromana de la Peninsula Ibérica", Actas del I Coloquio sobre Lenguas y Culturas Prerromanas de la Peninsula Ibérica (Salamanca, 27-31 Mayo 1974), Salamanca, 1976, pp. 57-86.

$\mathrm{AE}=$ L'Année Épigraphique, Paris, 1963, 1967, 1977, 1982 e 1984.

Blanco FreiJEIro (Antonio), El puente de Alcantara en su contexto historico, Madrid, 1977.

Cardoso (J. Ribeiro) Subsidios para a Historia Regional da Beira Baixa, vol. I, Castelo Branco, 1944.

Carvalho (J. Silva) e Ferreira (O. da Veiga), "Algumas lavras auríferas romanas", Estudos, Notas e Trabalhos do Serviço de Fomento Mineiro, vol. IX, fase. 1-4 1954, pp. 20-46.

CARValho (Rogério) e EnCARnaÇão (José d'), "Inscrição rupestre romana procedente de Capinha", Trebaruna, vol. III, Castelo Branco, 1994, pp. 43-53.

CIL II = HüBNER (E.), Corpus Inscriptionum Latinarum - II, Berlim, 1869.

Cortez (F. Russell), "Os Tapori de Plínio. Subsídios para a sua localização”, Zephyrus, III, 2, 1952, pp. 175-178.

* Quando às obras bibliográficas citadas ao longo deste trabalho se segue um número sem a sigla $\mathrm{p}$, indicativa de página, significa que se está a fazer referência ao número da inscrição na referida obra.

Conimbriga, 39 (2000) 153-189 
CPIL $=$ HuRTAdo De SAn ANTONIO (Ricardo), Corpus Provincial de Inscripciones Latinas (Cáceres), Cáceres, 1977.

Curado (Fernando Patrício), "Inscrição funerária de Mó do Douro (Vila Nova de Foz Coa) (Conventus Scallabitanus)”, Ficheiro Epigráfico, 14, 1985, pp. 11-13.

DiAs (M. Manuela A.), "A propósito da inscrição B-143 do Museu Regional de Beja”,

Conimbriga, XVIII, 1979, pp. 203-226.

Egitânia = ALmEIDA (D. Femando de), Egitánia. Historia e Arqueologia, Lisboa, 1956.

EnCARnaÇão (José d'), Sociedade e Epigrafia, Setúbal, 1979.

- "Uma estela do Museu de Évora (Conventus Pacensis)", Ficheiro Epigráfico, 4, 1982, pp. 11-12.

— "A Demografia" e " A Religião", in Alarcão (Jorge ) (Coord.) Nova História de Portugal, 1990, pp. 395-408 e 442-461.

- "O monumento epigráfico romano, fonte para o estudo das migrações na Península Ibérica", III Congreso Peninsular de Historia Antigua, Preactas, vol. II, Vitoria, 1994, pp. 649-653.

- Introdução ao Estudo da Epigrafia Latina, Coimbra, ${ }^{3} 1997$.

Étienne (Robert) e Fabre (G.), "C. Turranius Rufus de Conimbriga", Conimbriga, vol. XI, 1972, pp. 193-203.

Ferreira (Ana Paula), "As saudações do Além entre os Romanos", Conimbriga, vol. XXXV, 1996, pp. 107-127.

Garcia (José Manuel), "Epigrafia e romanização de Castelo Branco", Conimbriga, vol. XVIII, 1979, pp. 149-167.

- Epigrafia Lusitano-Romana do Museu Tavares Proença Júnior, Castelo Branco, 1984.

HAEp = Hispania Antiqua Epigraphica, Madrid, 1-3, 1950-1952; 4-5, 1953-1954; 6-7, 1955-1956; 12-16, 1961-1965.

HEp = Hispania Epigraphica, Madrid, n. ${ }^{\circ} 1,1989 ;$ n. ${ }^{\circ} 3,1993$.

ILER = VIVEs (J.), Inscripciones Latinas de la España Romana, Barcelona, 1971 e 1972 (índices).

IRCP = EnCARnaÇão (José d'), Inscrições Romanas do Conventus Pacensis, Coimbra, 1984.

KaJAnto (Iiro), The Latin Cognomina, Roma, ${ }^{2} 1982$.

LAMBrino (Scarlat), "Les inscriptions latines inédites du Musée Leite de Vasconcelos", O Arqueólogo Português, n. s., III, Lisboa, 1956, pp. 5-76.

Melena (José L.), "Un ara votiva romana en el Gaitán. Cáceres”, Veleia, 1, 1984, pp. 233-260.

Mantas (Vasco Gil), Recensão a José Manuel Garcia, Epigrafia Lusitano-Romana do Museu Tavares Proença Júnior, in Conimbriga, vol. XXIV, 1985, pp. 224-229 .

- "Orarium donavit Igaiditanis: Epigrafia e funções urbanas numa capital regional lusitana", ler Congreso Peninsular de Historia Antigua - Actas, vol. II, Santiago de Compostela, 1988, pp. 415-439.

Monteiro (José Alves), "Término de Peroviseu na Lusitânia Romana", Conimbriga, vol. XIII, 1974, pp. 57-62. 
Paço (Afonso do) e Almeida (D. Fernando de), "Duas inscrições inéditas do Museu de Marvão", Revista de Guimarães, vol. LXXII, n.os 1 e 2, 1962, pp. 145-151.

Palomar Lapes a (Manuel), La Onomástica Personal Pre-Latina de la Antigua Lusitania. Estudio Linguístico, Salamanca, 1957.

Rodrigues (Adriano Vasco), “A propósito de uma lápide do Mileu (Guarda)", Humanitas, vols. VI e VII, n. s., 1957-1958, pp. 96-99.

— "Elementos para o estudo da romanização nos Montes Herminios. I - Escavações da Póvoa de Mileu", Lucerna, vol. II, Porto, 1962, pp. 58-69.

STYLOW (Armín U.), "Beitráge zur lateinischen epigraphik im Norden der Provinz Córdoba", Madrider Mitteilungen, 27, 1986, pp. 243-245.

Untermann (Jürgen), Elementos de un Atlas Antroponimico de la Hispania Antigua, Madrid, 1965.

VAZ (João Luís), “Inscrições romanas do Museu do Fundão”, Conimbriga, XVI, 1977, pp. 1-32.

- A Civitas de Viseu. Espaço e Sociedade, CCRC, Coimbra, 1997. 


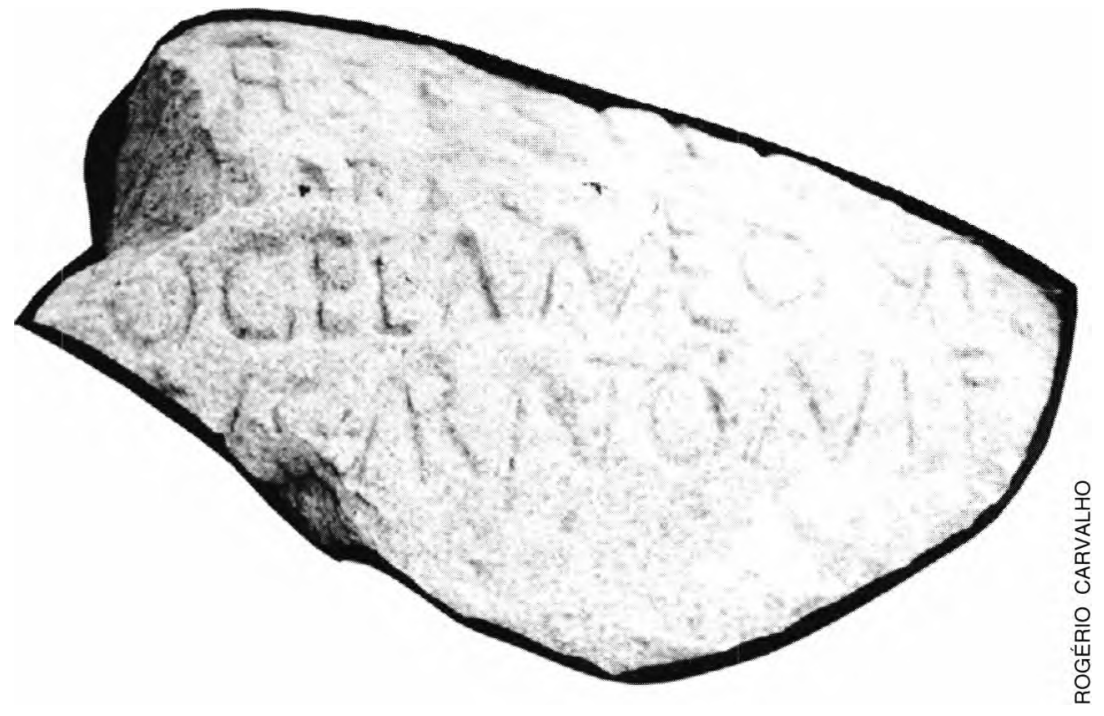

FOTO 1 - Inscrição $n \cdot{ }^{\circ} 4$

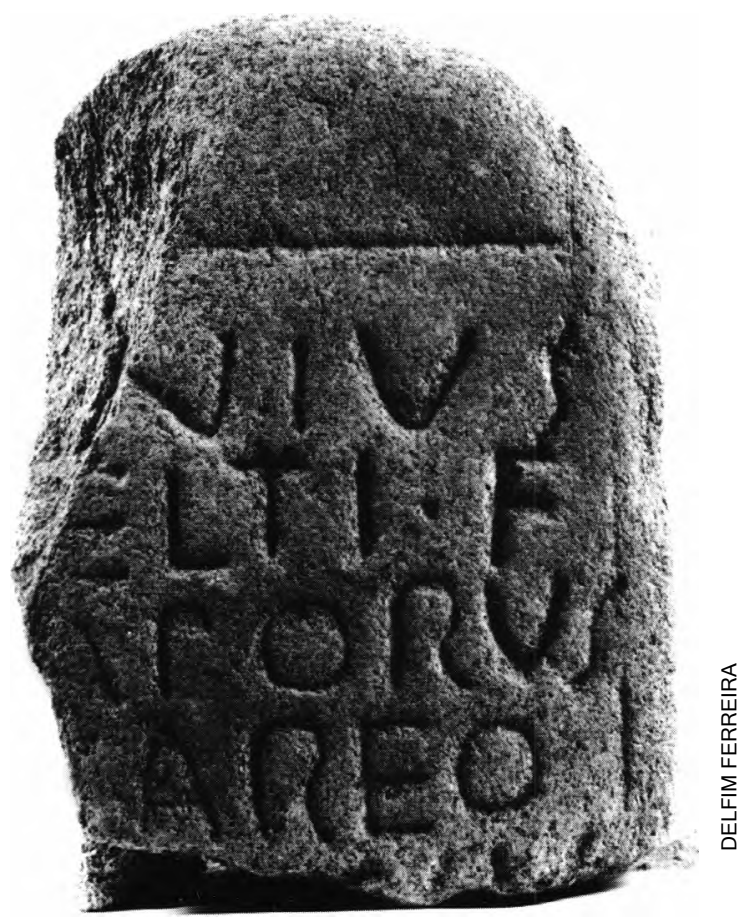

Fото 2 - Inscrição $n$. $^{\circ}$ 


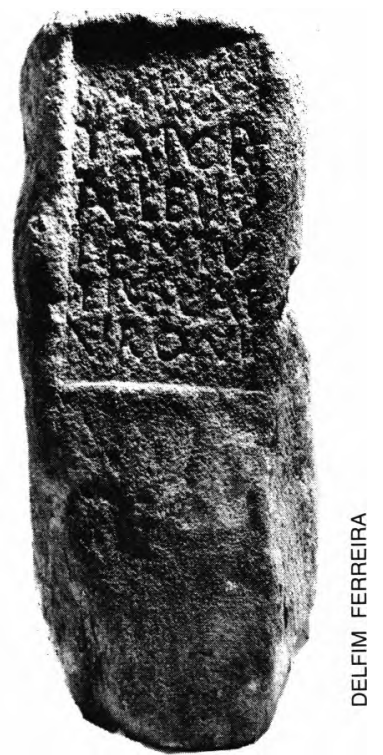

Fото 3 - Inscrição $n .{ }^{\circ} 8$

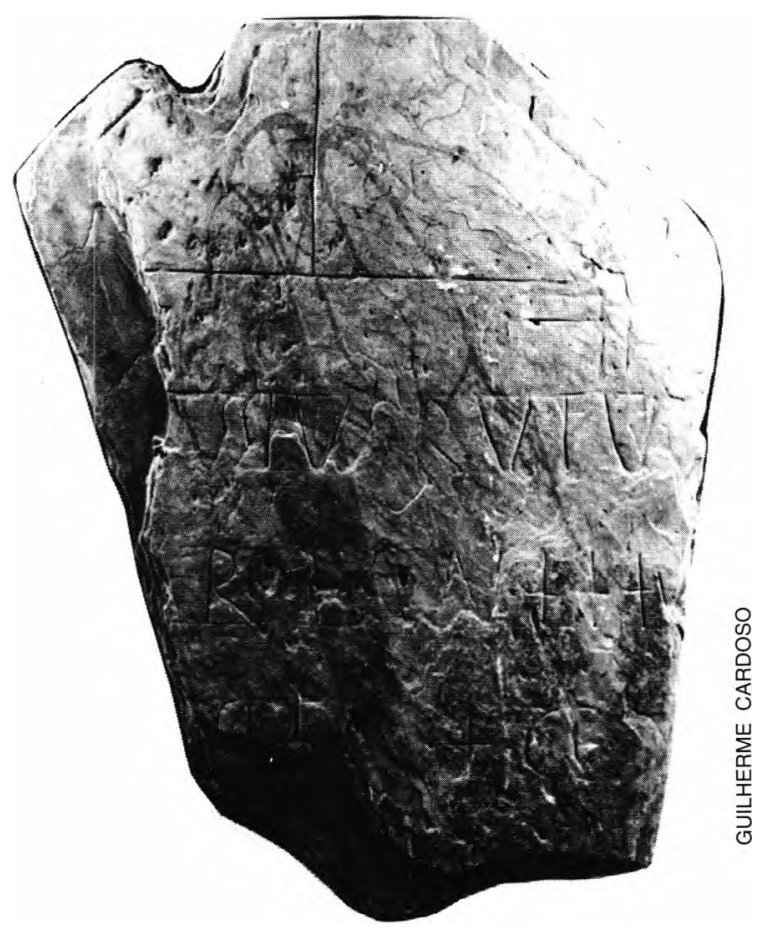

Fото 4 - Inscrição $n .^{\circ} 9$ 


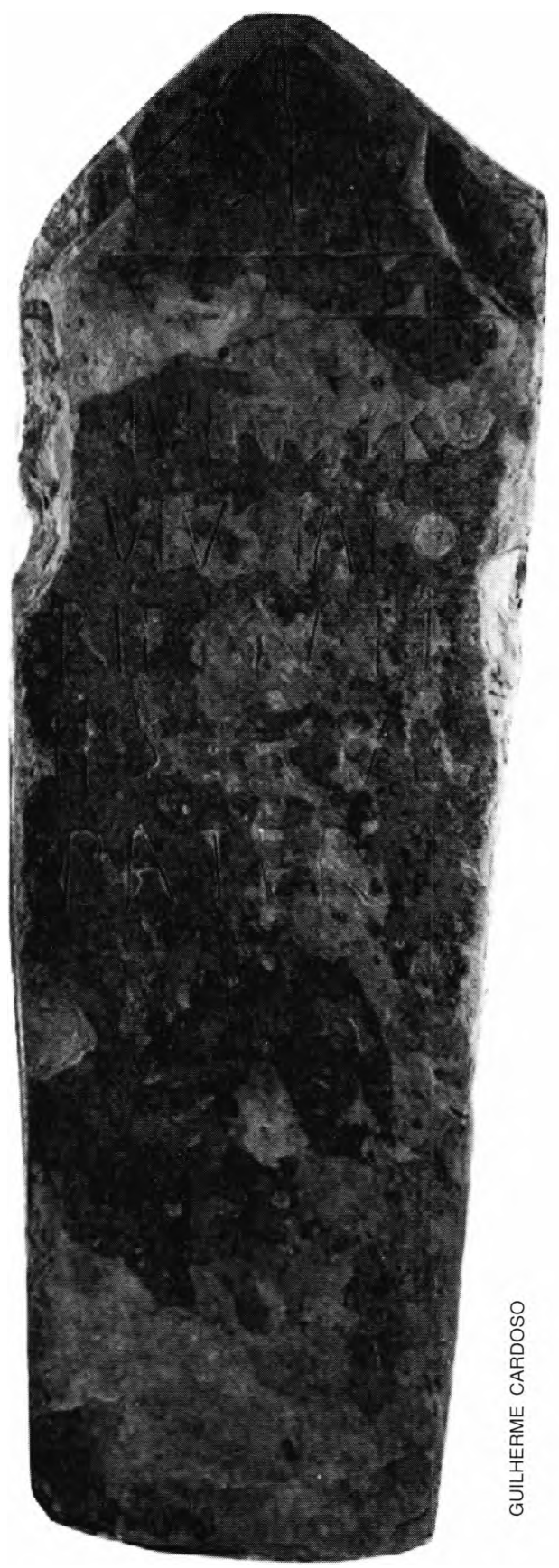

Fото 5 - Inscrição $n .^{\circ} 10$ 


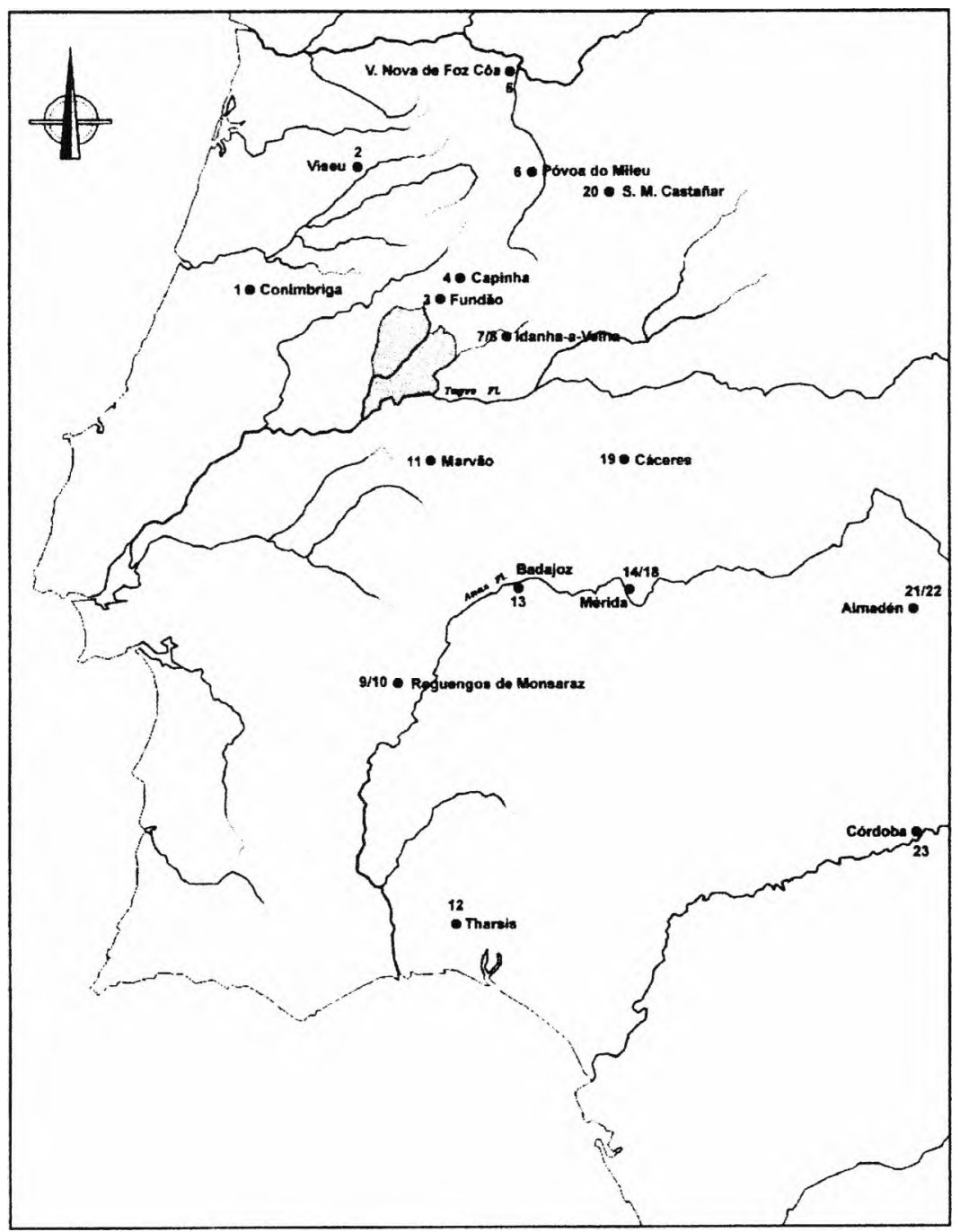

Proveniencia das epígrafes referentes a Tapori. 